Article

\title{
[AuHg(o- $\left.\left.\mathrm{C}_{6} \mathrm{H}_{4} \mathrm{PPh}_{2}\right)_{2} \mathrm{I}\right]:$ A Dinuclear Heterometallic Blue Emitter
}

\author{
José M. López-de-Luzuriaga *, Miguel Monge, M. Elena Olmos and David Pascual \\ Departamento de Química, Universidad de La Rioja. Centro de Investigación en Síntesis Química \\ (CISQ), Complejo Científico-Tecnológico, 26004-Logroño, Spain; \\ E-Mails: miguel.monge@unirioja.es (M.M.); m-elena.olmos@unirioja.es (M.E.O.); \\ david.pascualg@unirioja.es (D.P.)
}

* Author to whom correspondence should be addressed; E-Mail: josemaria.lopez@unirioja.es;

Tel.: +34-941-299-649.

Academic Editors: Antonio Laguna and Ahmed A. Mohamed

Received: 15 December 2014 / Accepted: 3 February 2015 / Published: 11 February 2015

\begin{abstract}
The heteronuclear $\mathrm{Au}^{\mathrm{I}} / \mathrm{Hg}^{\mathrm{II}}$ complex $\left[\mathrm{AuHg}\left(o-\mathrm{C}_{6} \mathrm{H}_{4} \mathrm{PPh}_{2}\right)_{2} \mathrm{I}\right](\mathbf{1})$ was prepared by reacting of $\left[\mathrm{Hg}\left(2-\mathrm{C}_{6} \mathrm{H}_{4} \mathrm{PPh}_{2}\right)_{2}\right]$ with $\left[\mathrm{Au}(\text { tht })_{2}\right] \mathrm{ClO}_{4}(1: 1)$ and $\mathrm{NaI}$ in excess. The heterometallic compound $\mathbf{1}$ has been structurally characterized and shows an unusual blue luminescent emission in the solid state. Theoretical calculations suggest that that the origin of the emission arises from the iodide ligand arriving at metal-based orbitals in a Ligand to Metal-Metal Charge Transfer transition.
\end{abstract}

Keywords: gold; mercury; metal-metal interactions; theoretical calculations; luminescence

\section{Introduction}

Complexes with metallophilic interactions have been the subjects of intense research in the last few years. The interest in this type of complexes covers several areas of research, including, among others, supramolecular structural analysis or theoretical calculations on the nature of the metallophilic interactions [1-4]. Furthermore, the complexes that present these interactions, usually exhibit interesting photoluminescent or vapochromic properties of relevance for applications in luminescence signaling and vapochemical sensing [5-7]. 
Regarding this topic, our research group has been devoted to the synthesis of new compounds bearing metallophilic interactions between heavy closed shell metal ions, with gold occupying a preferential position among them. Thus, we have succeeded in synthesizing a number of complexes displaying interactions between gold(I) and other closed shell metal centers. The synthetic and theoretical study of this type of interactions is still nowadays a challenge because of their implications in the structure and properties of the complexes that contain them. Thus, we have described complexes with $\mathrm{d}^{10}-\mathrm{d}^{10}$ interactions between $\mathrm{Au}^{\mathrm{I}}$ and their group congeners $\mathrm{Ag}^{\mathrm{I}}$ or $\mathrm{Cu}^{\mathrm{I}}[8-13]$; $\mathrm{d}^{10}-\mathrm{d}^{8}$ interactions as, for instance, those appearing in the complexes $\left[\mathrm{Hg}\left\{\mathrm{Au}\left(\mathrm{C}_{6} \mathrm{~F}_{5}\right) \mathrm{Cl}_{2}\left(\mu-2-\mathrm{C}_{6} \mathrm{H}_{4} \mathrm{PPh}_{2}\right)\right\}_{2}\right]$ or $\left[\left\{\mathrm{AuCl}\left(\mathrm{Ph}_{2} \mathrm{PCH}_{2} \mathrm{SPh}\right)\right\}_{2} \mathrm{PdCl}_{2}\right][14,15]$; or with post-transition metals as $\mathrm{Tl}^{\mathrm{I}}, \mathrm{Sn}^{\mathrm{II}}$ or $\mathrm{Bi}^{\mathrm{III}}$, in which the interactions are of the type $\mathrm{d}^{10}-\mathrm{s}^{2}$ [16-18]. In addition, very recently, we reported the synthesis of complexes displaying unsupported $\mathrm{Au}^{\mathrm{I}}-\mathrm{Hg}^{\mathrm{II}}$ interactions, that in addition to their interesting structural characteristics show fascinating luminescent properties or even the capability to quench very effectively the emission of organic molecules [19,20].

Regarding the luminescent properties, from a practical viewpoint, the greater efforts are oriented to obtain blue emissive compounds. However, the number of heterometallic compounds that emit in the blue range is still comparatively very scarce. For instance, in our case, from all the complexes studied only in the case of the complexes $\left[\left\{\mathrm{AuTl}\left(\mathrm{C}_{6} \mathrm{Cl}_{5}\right)_{2} \text { (toluene) }\right\}_{2}\right.$ (dioxane) $),\left\{\left[\mathrm{Tl}\left(\eta^{6}\right.\right.\right.$-toluene) $]$ $\left.\left[\mathrm{Au}\left(\mathrm{C}_{6} \mathrm{Cl}_{5}\right)_{2}\right]\right\},\left[\left\{\mathrm{Au}\left(\mathrm{C}_{6} \mathrm{Cl}_{5}\right)_{2}\right\} \mathrm{Ag}\left([14] \mathrm{aneS}_{4}\right)\right]$ or $\left[\left\{\mathrm{Au}\left(\mathrm{C}_{6} \mathrm{~F}_{5}\right)_{2}\right\} \mathrm{Tl}([14] \text { aneS} 4)\right]_{2}$ present this color in their emissions [21-23]. From our studies we have concluded that one of the conditions that must be met to obtain blue luminescent compounds is that their molecular structures must consist preferably of discrete units instead of the most common extended 1-D, 2-D, or even 3-D structures. The main reason is that the structures in which the dimensionality is built by metallophilic contacts, the luminescence is usually based in metal centered emissions, and the polymeric nature of these species provokes the delocalization of the exciton along the chains of metals, a lower HOMO-LUMO gap and, therefore, low energy emissions. Consequently, molecules displaying intermetallic interactions, but with lower dimensionality, should present higher energy emissions.

Thus, in this paper we report the synthesis and characterization of the complex $[\operatorname{AuHg}(o-$ $\left.\left.\mathrm{C}_{6} \mathrm{H}_{4} \mathrm{PPh}_{2}\right)_{2} \mathrm{I}\right](\mathbf{1})$, whose molecular nature in solid state and in solution permits it to behave as a blue emitter. In addition, in this paper we describe its photophysical properties and a theoretical interpretation of the excited state properties by mean of MP 2 calculations.

\section{Results and Discussion}

\subsection{Synthesis and Characterization}

The synthetic strategy in this case consisted of the use of a metal precursor bearing unsaturated donor centers and its reaction with a metal atom coordinated to labile ligands, with the simultaneous presence of an anion with affinity for one of the metal centers. With these conditions we hinder the polymerization by intermetallic contacts between different molecules by blocking one position.

Thus, the reaction of $\left[\mathrm{Hg}\left(o-\mathrm{C}_{6} \mathrm{H}_{4} \mathrm{PPh}_{2}\right)_{2}\right]$ with an equimolecular amount of $\left[\mathrm{Au}(\mathrm{tht})_{2}\right] \mathrm{ClO}_{4}$ in dichloromethane and an excess of an aqueous solution of $\mathrm{NaI}$ produces the coordination of the gold center to the phosphine ligands by displacement of the tht ligands and simultaneous substitution of the 
$\mathrm{ClO}_{4}{ }^{-}$anion by $\mathrm{I}^{-}$, forming the complex $\left[\mathrm{AuHg}\left(o-\mathrm{C}_{6} \mathrm{H}_{4} \mathrm{PPh}_{2}\right)_{2} \mathrm{I}\right]$ (1) (See Scheme 1). The electrospray (-) high-resolution mass spectrum of 1 shows a peak that corresponds to the anion $\mathrm{I}^{-}$at $\mathrm{m} / z=126.90$. In addition, the signal corresponding to the cation $\left[\mathrm{AuHg}\left(o-\mathrm{C}_{6} \mathrm{H}_{4} \mathrm{PPh}_{2}\right)_{2}\right]^{+}$also appears in its electrospray (+) spectrum at $m / z=921.11$. The ${ }^{31} \mathrm{P}\left\{{ }^{1} \mathrm{H}\right\} \mathrm{NMR}$ spectrum of $\mathbf{1}$ in $\mathrm{CDCl}_{3}$ shows a unique singlet at $\delta=39.9 \mathrm{ppm}$, indicating the magnetic equivalence of both phosphorous atoms present in this complex, as well as the coordination of the phosphine ligands to the gold center in solution due to the deshielding of the original position at $-1.8 \mathrm{ppm}$ in the starting mercury derivative $\left[\mathrm{Hg}\left(o-\mathrm{C}_{6} \mathrm{H}_{4} \mathrm{PPh}_{2}\right)_{2}\right]$. Interestingly, the conductivity measurement of complex $\mathbf{1}$ in dichloromethane solution gives a value of $0.1 \Omega^{-1} \cdot \mathrm{cm}^{2} \cdot \mathrm{mol}^{-1}$, indicating that the iodine anion, instead of dissociating in solution, is bonded to a metal center. The remaining analytical and spectroscopic data are in accordance with the proposed structure (see Experimental Section).
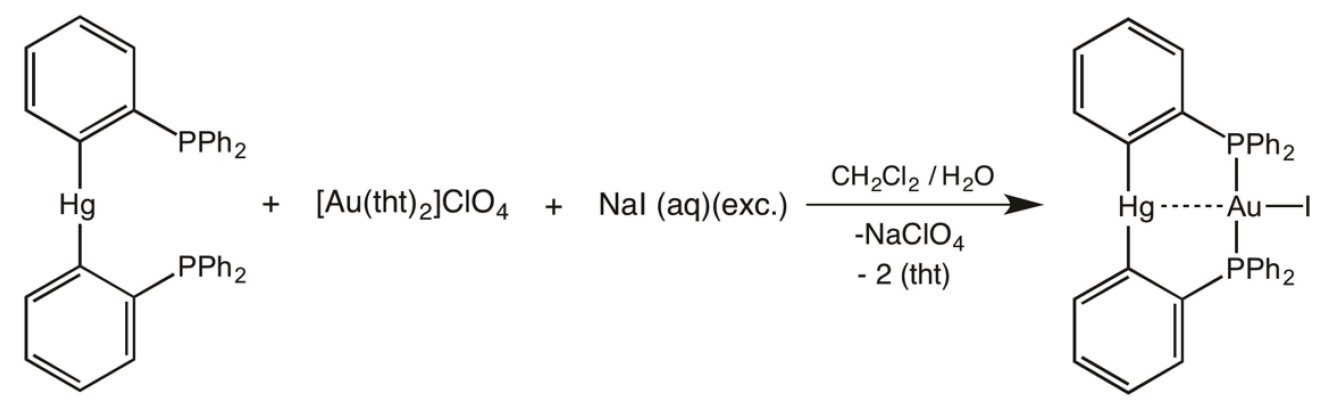

1

Scheme 1. Synthesis of complex 1.

\subsection{Crystal Structure}

The crystal structure of $\left[\mathrm{AuHg}\left(o-\mathrm{C}_{6} \mathrm{H}_{4} \mathrm{PPh}_{2}\right)_{2} \mathrm{I}\right] \cdot \mathrm{CH}_{2} \mathrm{Cl}_{2}$ (1) was determined by X-ray diffraction from single crystals obtained by slow diffusion of $n$-hexane into a solution of the complex in dichloromethane. Compound 1 crystallizes in the monoclinic space group P2/a with a molecule of $\mathrm{CH}_{2} \mathrm{Cl}_{2}$ per molecule of compound.

The crystal structure of $\left[\mathrm{AuHg}\left(o-\mathrm{C}_{6} \mathrm{H}_{4} \mathrm{PPh}_{2}\right)_{2} \mathrm{I}\right] \cdot \mathrm{CH}_{2} \mathrm{Cl}_{2}(\mathbf{1})$ shows an eight-member dimetallacycle in a twisted conformation, which is formed by both metal atoms and two $\mathrm{PC}_{2}$ fragments of the bridging ligands in a head-to-head disposition with $\mathrm{Au}-\mathrm{P}$ and $\mathrm{Hg}-\mathrm{C}$ bonds (see Figure 1). Additionally, a iodine atom is bonded to the gold center with a Au-I bond distance of 2.8998(3) $\AA$, lying within the range 2.8052(4)-3.0831(7) $\AA$, observed for other related dinuclear gold(I) species of the type $\left[\operatorname{Au}_{2}(\mu-\right.$ diphosphine $)_{2} \mathrm{I}_{2}$ ] containing three-coordinated gold(I) atoms [24-27], and identical to that found in $\alpha$ $\mathrm{Au}_{2}(\mu \text {-dppe })_{2} \mathrm{I}_{2} \cdot 2 \mathrm{OCMe}_{2}(2.906(2) \AA)$ [24]. The gold center binds to both phosphorus with Au-P bond distances of 2.3295(11) and 2.3323(11) $\AA$, which compare well with most of the Au-P bond lengths described for the related complexes cited above (2.2997(6)-2.342(3) $\AA$ ) [24-27]. The crystal structure of 1 reveals a distorted T-shaped geometry at the gold atom if the intermetallic interaction is not considered. Although the P-Au-P angle shows a marked deviation from linearity (P-Au-P = $\left.154.28(4)^{\circ}\right)$, the $\mathrm{AuP}_{2} \mathrm{I}$ unit is planar, with a sum of the two P-Au-I angles and the P-Au-P one of $359.94^{\circ}$. Similar situations have been found in $\left[\mathrm{Au}_{2}\left(\mu-\mathrm{PPh}_{2}\left(\mathrm{CH}_{2}\right)_{3} \mathrm{PPh}_{2}\right)_{2}\right] \mathrm{I}_{2}$ [25] or in $\left[\mathrm{Au}_{2}(\mathrm{dcpm})_{2}\right] \mathrm{I}_{2}$ $(\mathrm{dcpm}=$ bis(dicyclohexylphosphino)methane) [27], which show P-Au-P angles of 157.93(7) or 
$152.88(3)^{\circ}$, respectively, and a planar three-coordinate environment for $\mathrm{Au}^{\mathrm{I}}$. The intermetallic distance of 3.0943(2) A, shorter than the sum of the Van der Waals radii of gold and mercury (3.21 $\AA$ ) [28], evidences the presence of a $\mathrm{Au}^{\mathrm{I}} \cdots \mathrm{Hg}^{\mathrm{II}}$ contact. This value is intermediate between the maximum and minimum $\mathrm{Au}-\mathrm{Hg}$ distances found in the literature for other complexes displaying supported $\mathrm{Au} \cdots \mathrm{Hg}$ interactions: $\left[\mathrm{HgAu}\left(\mathrm{CH}_{2} \mathrm{SPPh}_{2} \mathrm{CH}_{2}\right)_{2}\right] \mathrm{PF}_{6} \quad(2.934(1) \quad \AA) \quad[29] ; \quad\left[\mathrm{AuHg}(\mathrm{Cl})_{2}\left(o-\mathrm{C}_{6} \mathrm{H}_{4} \mathrm{PPh}_{2}\right)\right] \quad(3.112(1) \quad \AA) \quad[30] ;$ $\left[\mathrm{HgAu}\left(\mathrm{SPPh}_{2} \mathrm{CH}_{2}\right)_{2}\right] \mathrm{PF}_{6}(3.079(2) \AA)$ [31]; or $\left[\mathrm{Hg}\left(\mathrm{CH}_{2} \mathrm{P}(\mathrm{S}) \mathrm{PPh}_{2}\right)_{2}(\mathrm{AuCl})_{2}\right]$ (3.310(1) $\AA$ ) [31]. Finally, the mercury(II) center is nearly linearly coordinated to two carbon atoms $\left(\mathrm{C}-\mathrm{Hg}-\mathrm{C}=175.46(17)^{\circ}\right)$ showing typical Hg-C (2.090(4) and 2.096(4) ^̊) bond distances for an aryl-mercury(II) coordination. Taking into account the $\mathrm{Au} \cdots \mathrm{Hg}$ interaction, the coordination environment of mercury can be described as T-shape, since the intermetallic contact is orthogonal to the $\mathrm{C}-\mathrm{Hg}-\mathrm{C}$ axis $(\mathrm{C}-\mathrm{Hg}-\mathrm{Au}=$ 90.30(12) and 92.29(12) $)^{\circ}$ (see Table 1).

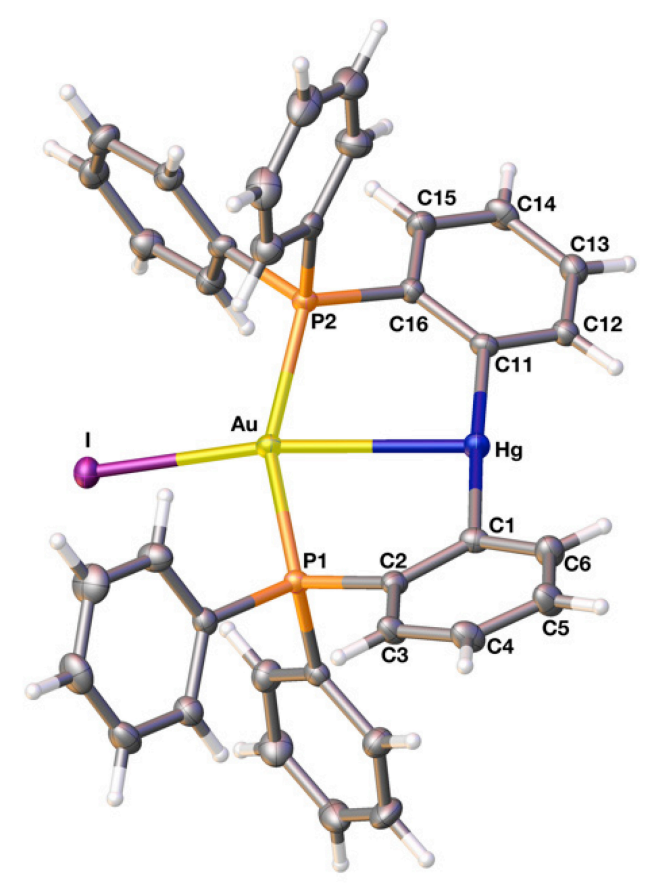

Figure 1. Crystal structure of compound 1.Thermal ellipsoid are set at 35\% probability.

Table 1. Selected bond lengths $(\AA)$ and angles $\left(^{\circ}\right)$ for complex $\mathbf{1}$.

\begin{tabular}{cc}
\hline Bond Distance $(\AA) /$ Angle $\left.^{\circ}\right)$ & $\mathbf{1}$ \\
\hline $\mathrm{Au}-\mathrm{Hg}$ & $3.0944(2)$ \\
$\mathrm{Au}-\mathrm{P}(1)$ & $2.3298(11)$ \\
$\mathrm{Au}-\mathrm{P}(2)$ & $2.3323(11)$ \\
$\mathrm{Au}-\mathrm{I}$ & $2.8997(3)$ \\
$\mathrm{Hg}-\mathrm{C}(1)$ & $2.097(4)$ \\
$\mathrm{Hg}-\mathrm{C}(11)$ & $2.090(4)$ \\
$\mathrm{P}(1)-\mathrm{Au}-\mathrm{P}(2)$ & $154.25(4)$ \\
$\mathrm{I}-\mathrm{Au}-\mathrm{Hg}$ & $163.150(9)$ \\
$\mathrm{C}(1)-\mathrm{Hg}-\mathrm{C}(11)$ & $175.47(16)$ \\
\hline
\end{tabular}




\subsection{Photophysical Properties and Theoretical Calculations}

Usually, complexes displaying $\mathrm{Au}(\mathrm{I})-\mathrm{M}(\mathrm{I})(\mathrm{M}$ = coinage metals) or $\mathrm{Au}(\mathrm{I})-\mathrm{Hg}(\mathrm{II})$ interactions show emission lifetimes in the nanosecond range, and colors in the yellow-orange range of the visible spectrum, which was assigned to delocalized excitons in extended chains or two- or three-dimensional networks [8-13,19,20]. Only a few cases complexes behave as blue emitters and show longer (microsecond) lifetimes. These consist of discrete heterometallic units [21-23] or localized excitons in polynuclear systems. Complex 1 is an example of the latter. It shows an unusual blue luminescence at room temperature in solid state $\left(\lambda_{\mathrm{em}}=456 \mathrm{~nm}\left(\lambda_{\text {exc. }}=367 \mathrm{~nm}\right)\right)$ and at $77 \mathrm{~K}\left(\lambda_{\mathrm{em} .}=475 \mathrm{~nm}\left(\lambda_{\text {exc. }}=363 \mathrm{~nm}\right)\right)(\mathrm{see}$ Table 2), however, in dichloromethane solutions its emissive properties are lost. This fact can be due to the formation of non-luminescent exciplexes with solvent molecules in the excited state. The absorption spectrum in a $3 \times 10^{-5} \mathrm{M} \mathrm{CH}_{2} \mathrm{Cl}_{2}$ solution shows a band centered at $236 \mathrm{~nm}\left(\varepsilon=32920 \mathrm{M}^{-1} \cdot \mathrm{cm}^{-1}\right)$ that is also present in the mercury precursor absorption spectrum (see Figure 2). This band can be tentatively assigned to a $\pi-\pi *$ intraligand transition. Additionally, the spectrum of $\left[\mathrm{AuHg}\left(o-\mathrm{C}_{6} \mathrm{H}_{4} \mathrm{PPh}_{2}\right)_{2} \mathrm{I}\right]$ (1) shows a band of very low intensity at $357 \mathrm{~nm}\left(\varepsilon=1246 \mathrm{M}^{-1} \cdot \mathrm{cm}^{-1}\right)$ that is not present in the mercury precursor. This new band appears approximately at the same energy than the excitation (see inset of the Figure 2) and can be assigned to a spin forbidden $\mathrm{S}_{0} \rightarrow \mathrm{T}_{1}$ transition. The lifetime in the microsecond range $(1.57 \mu \mathrm{s})$ together with the large Stokes shift $\left(5314 \mathrm{~cm}^{-1}\right)$ suggest a phosphorescent emission.

Table 2. Photophysical properties of $\left[\mathrm{AuHg}\left(o-\mathrm{C}_{6} \mathrm{H}_{4} \mathrm{PPh}_{2}\right)_{2} \mathrm{I}\right](\mathbf{1})$.

\begin{tabular}{cccc}
\hline Complex & Medium (T $[\mathbf{K}])$ & $\lambda_{\text {abs }}[\mathbf{n m}]\left(\boldsymbol{\varepsilon}\left[\mathbf{M}^{-\mathbf{1}} \mathbf{c m}^{-\mathbf{1}}\right]\right)$ & $\begin{array}{c}\left.\lambda_{\text {em }}\left(\lambda_{\text {exc }}\right)[\mathbf{n m}] / \boldsymbol{\tau}[\boldsymbol{\mu s}] /\right] / \mathbf{\Phi} \\
(\mathbf{\%})\end{array}$ \\
\hline \multirow{2}{*}{1} & $\mathrm{CH}_{2} \mathrm{Cl}_{2}(\mathrm{RT})$ & $236(32920), 357(1246)$ & - \\
& Solid (RT) & & $456(367) / 1.57 / 27.6$ \\
& Solid (77K) & & $475(363)$ \\
\hline
\end{tabular}
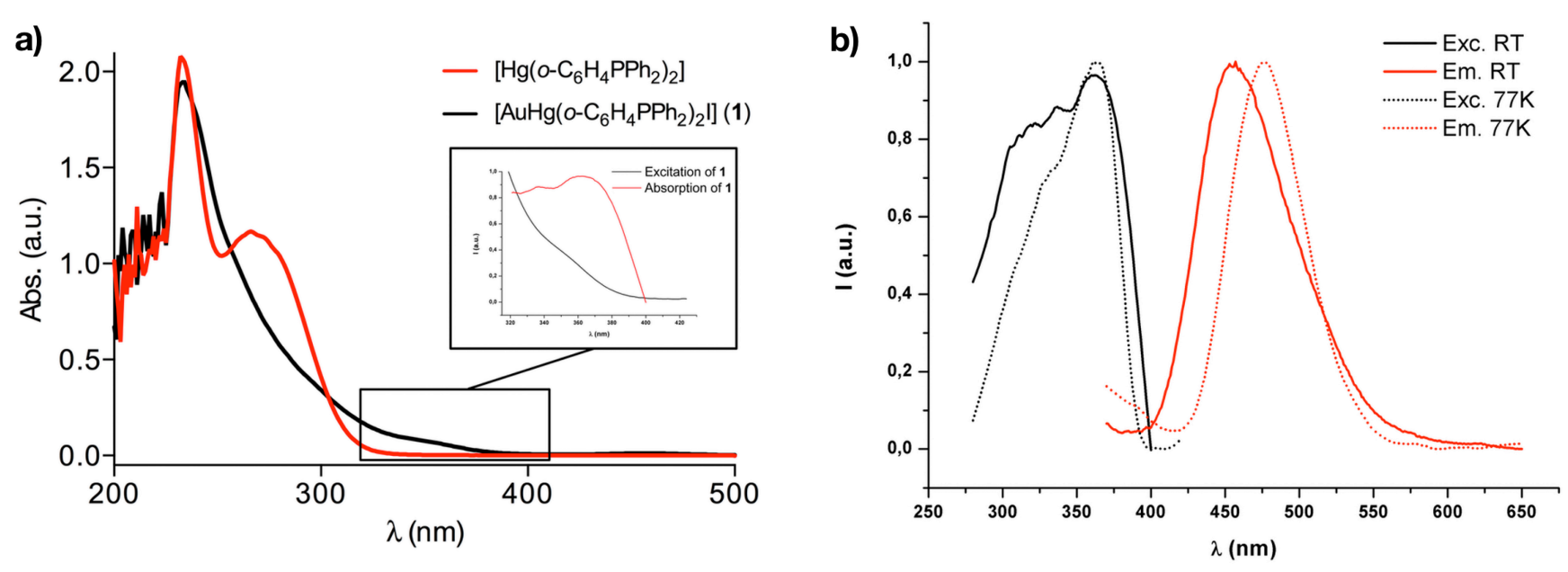

Figure 2. (a) UV-vis spectrum for complexes $\left[\mathrm{Hg}\left(o-\mathrm{C}_{6} \mathrm{H}_{4} \mathrm{PPh}_{2}\right)_{2}\right]$ (red) and 1 (black) in dichloromethane solutions. (b) Normalized excitation (black) and emission (red) spectra in the solid state at RT (solid line) and emission at $77 \mathrm{~K}$ (dotted line) for complexes $\mathbf{1}$. 
In view of the interesting photophysical properties displayed by this heterometallic $\mathrm{Au}(\mathrm{I}) \cdots \mathrm{Hg}(\mathrm{II})$ complex we have carried out computational studies to deepen into the origin of this behavior. For this, we have carried out ab initio 2nd order Moller-Plesset (MP2) calculations on the dinuclear model system $\left[\mathrm{AuHg}\left(o-\mathrm{C}_{6} \mathrm{H}_{4} \mathrm{PH}_{2}\right)_{2} \mathrm{I}\right]$ (1a) (See Computational Details). This level of theory has been chosen since it has been repeatedly proven to reproduce the dispersive origin of the metallophilic interactions observed experimentally [2-4].

We have fully optimized model $\mathbf{1 a}$ without any symmetry constrains, both in the ground $\left(\mathrm{S}_{0}\right)$ and lowest triplet excited state $\left(T_{1}\right)$. The ground state optimization of model 1a provides important information: first, the optimized structural parameters can be compared with the experimental ones, including the intermetallic closed-shell $\mathrm{Au}(\mathrm{I}) \cdots \mathrm{Hg}(\mathrm{II})$ interaction distance, what permits to validate the level of theory chosen and, second, the shape of the highest occupied molecular orbital (HOMO) shows the part of the molecule from which the electronic excitation related to the photoluminescent behavior of this complex arises. On the other hand, the lowest triplet excited state $\left(\mathrm{T}_{1}\right)$ structural optimization also provides interesting results: first, the structural distortions observed in the $\mathrm{S}_{0} \rightarrow \mathrm{T}_{1}$ electronic excitation rely information about which part of the molecule would be involved in the experimentally observed phosphorescent transition and, second, the shape of the highest simply occupied molecular orbital (SOMO) to which the electron arrives in the $\mathrm{S}_{0} \rightarrow \mathrm{T}_{1}$ excitation permits to confirm the origin of the emissive properties.

As is depicted in Table 3 the full optimization of model $\mathbf{1 a}$ in the $\mathrm{S}_{0}$ state shows similar structural parameters to the ones experimentally obtained for complex $\mathbf{1}$ through X-ray diffraction analysis. It is worth mentioning that the MP2 level of theory, which includes correlation effects, leads to a good agreement between the theoretically predicted and the experimentally obtained $\mathrm{Au}(\mathrm{I}) \cdots \mathrm{Hg}(\mathrm{II})$ intermetallic distances $(\mathrm{d}(\mathrm{Au}-\mathrm{Hg})=3.05$ (theor.) $3.09 \AA$ (exp.)), and for the coordination environments of the metal centers. The slight deviation of the theoretically predicted $\mathrm{Hg}$-Au-I angle $\left(168.4^{\circ}\right)$ with respect to the experimental one $\left(176.2^{\circ}\right)$ would be related with the fact that the theoretical model is calculated in the gas phase where packing effects are not considered. In the next step we have carried out the full optimization of the lowest triplet excited state $\left(T_{1}\right)$ for model 1a. This $T_{1}$ state displays important structural distortions around the metal centers. The most important distortion consists of a large shortening of the intermetallic $\mathrm{Au}-\mathrm{Hg}$ distance from 3.05 in the ground $\mathrm{S}_{0}$ state to $2.79 \AA$ in the lowest triplet $\mathrm{T}_{1}$ state, leading to a very short metal-metal interaction. In contrast, an appreciable increase of the Au-P distances is observed, going from $2.35\left(\mathrm{~S}_{0}\right)$ to $2.46 \AA$ ( $\left.\mathrm{T}_{1}\right)$ (see Table 3 and Figure 3 ). The rest of bond distances obtained for model $1 \mathbf{a}$ in the $\mathrm{T}_{1}$ state only suffer slight changes with respect to the $\mathrm{S}_{0}$ state. Also, the P-Au-P angle bents outwards from $157.4^{\circ}$ in the ground state to $168.5^{\circ}$ in the lowest triplet excited state, pushing the $\mathrm{Au}(\mathrm{I})$ center closer to the $\mathrm{Hg}(\mathrm{II})$ one. Overall, since the $\mathrm{T}_{1}$ excited state distortions found for model 1 a can be related to a main change of the $\mathrm{Au}$ (I) and $\mathrm{Hg}$ (II) coordination environments and, specially, a shortening of the $\mathrm{Au}(\mathrm{I}) \cdots \mathrm{Hg}(\mathrm{II})$ metallophilic distance, the phosphorescent properties of this complex could be ascribed to a $\mathrm{S}_{0} \rightarrow \mathrm{T}_{1}$ electronic transition involving these interacting closed-shell metals.

Another interesting result that can be derived from the full optimization of model $\mathbf{1 a}$ in the $\mathrm{S}_{0}$ and $\mathrm{T}_{1}$ states is the analysis of the frontier molecular orbitals (MOs) for each model systems. In a phosphorescent process we can attribute the origin of the emissive properties to an electronic transition between the HOMO (Highest Occupied Molecular Orbital) in the $\mathrm{S}_{0}$ ground state and the SOMO 
(Singly Occupied Molecular Orbital) in the $\mathrm{T}_{1}$ state. The frontier MOs for model 1a in the $\mathrm{S}_{0}$ (HOMO and LUMO) and $\mathrm{T}_{1}$ (SOMO and SOMO-1) states are depicted in Figure 4. The HOMO orbital in model 1a is mainly located at a $5 p$ antibonding orbital of the iodide ligand with a small contribution of the gold center. On the other hand the SOMO is a $6 s / 6 p$ bonding orbital to which the electron arrives in the $\mathrm{S}_{0} \rightarrow \mathrm{T}_{1}$ electronic transition and that is mostly placed at the interacting $\mathrm{Au}(\mathrm{I}) \cdots \mathrm{Hg}(\mathrm{II})$ closed-shell metal centers. It is worth mentioning that this bonding character of the SOMO orbital would be related to the $\mathrm{Au}-\mathrm{Hg}$ distance shortening since a bond order increase between the metals would take place upon the electron excitation from the antibonding $5 p$ orbital at the iodide ligand to the bonding $6 s / 6 p$ metal-based bonding orbital. Therefore, in view of the shape of the HOMO and SOMO orbitals and, taking also into account the structural distortions described above for the $\mathrm{T}_{1}$ state with respect to the $\mathrm{S}_{0}$ one, we suggest that the origin of the phosphorescence for complex $\mathbf{1}$ is a forbidden Ligand to Metal-Metal Charge Transfer transition from the iodide ligand to the interacting $\mathrm{Au}(\mathrm{I}) \cdots \mathrm{Hg}(\mathrm{II})$ metal centers ${ }^{3}$ (LMMCT).
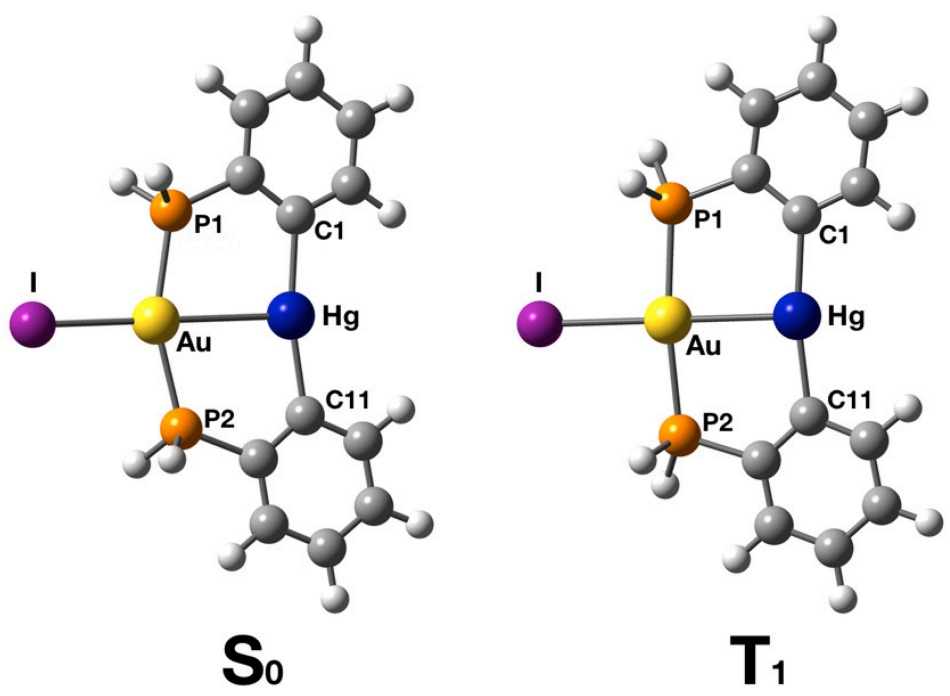

Figure 3. Fully optimized model system $\left[\mathrm{AuHg}\left(o-\mathrm{C}_{6} \mathrm{H}_{4} \mathrm{PH}_{2}\right)_{2} \mathrm{I}\right](\mathbf{1 a})$ in the ground $\left(\mathrm{S}_{0}\right)$ (left) and the lowest triplet excited state $\left(\mathrm{T}_{1}\right)$ (right).

Table 3. Selected experimental and theoretical distances $(\AA)$ and angles $\left(^{\circ}\right)$ for complex $\left[\operatorname{AuHg}\left(o-\mathrm{C}_{6} \mathrm{H}_{4} \mathrm{PPh}_{2}\right)_{2} \mathrm{I}\right](\mathbf{1})$ and model $\left[\mathrm{AuHg}\left(o-\mathrm{C}_{6} \mathrm{H}_{4} \mathrm{PH}_{2}\right)_{2} \mathrm{I}\right](\mathbf{1 a})$ in the ground $\left(\mathrm{S}_{0}\right)$ and excited $\left(\mathrm{T}_{1}\right)$ states.

\begin{tabular}{cccc}
\hline Distances/Angles & Exp. in $\mathbf{1}$ & $\mathbf{S}_{\mathbf{0}}$ in 1a & $\mathbf{T}_{\mathbf{1}}$ in 1a \\
\hline $\mathrm{Au}-\mathrm{Hg}$ & 3.09 & 3.05 & 2.79 \\
$\mathrm{Au}-\mathrm{P} 1$ & 2.33 & 2.35 & 2.46 \\
$\mathrm{Au}-\mathrm{P} 2$ & 2.33 & 2.35 & 2.46 \\
$\mathrm{Au}-\mathrm{I}$ & 2.90 & 2.78 & 2.76 \\
$\mathrm{Hg}-\mathrm{C} 1$ & 2.10 & 2.13 & 2.13 \\
$\mathrm{Hg}-\mathrm{C} 11$ & 2.09 & 2.13 & 2.13 \\
$\mathrm{Hg}-\mathrm{Au}-\mathrm{I}$ & 163.2 & 180.0 & 179.0 \\
$\mathrm{P} 1-\mathrm{Au}-\mathrm{P} 2$ & 154.3 & 157.4 & 168.3 \\
$\mathrm{C} 1-\mathrm{Hg}-\mathrm{C} 11$ & 175.5 & 168.4 & 170.5 \\
\hline
\end{tabular}



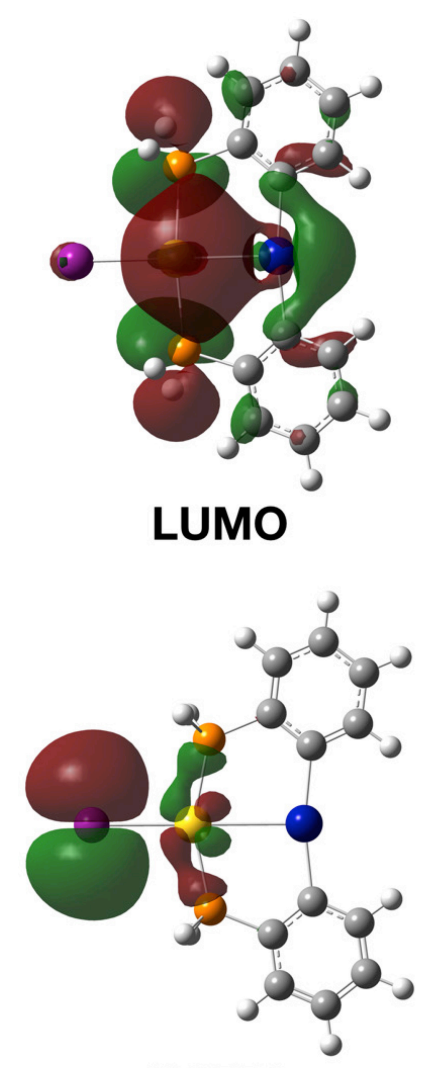

HOMO

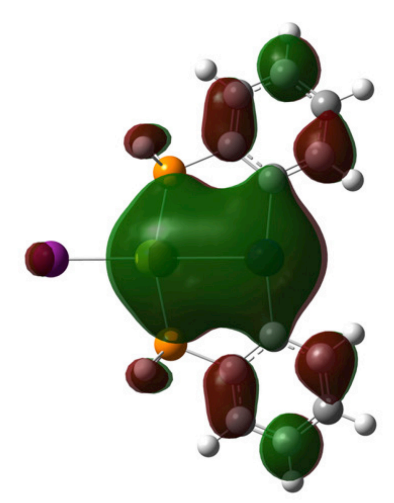

SOMO

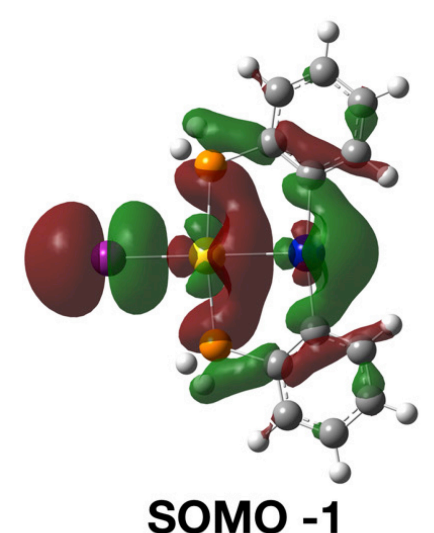

Figure 4. Frontier molecular orbitals for the model system $1 \mathbf{a}$ in the $\mathrm{S}_{0}$ and $\mathrm{T}_{1}$ states.

\section{Experimental Section}

\subsection{General Considerations}

All reactions were carried out under argon atmosphere using Schlenk techniques. All solvents were dry and deoxygenated. Solvents used in the spectroscopic studies were degassed prior to use. $\left[\mathrm{Au}(\text { tht })_{2}\right] \mathrm{ClO}_{4}$ and $\left[\mathrm{Hg}\left(2-\mathrm{C}_{6} \mathrm{H}_{4} \mathrm{PPh}_{2}\right)_{2}\right]$ were prepared according to literature methods [32,33]. Caution! Due to the toxicity of mercury compounds extra care was taken to avoid contact with solid, solution, and airborne mercury products.

\subsection{Instrumentation}

Carbon and hydrogen analyses were carried out with a Perkin-Elmer $240 \mathrm{C}$ microanalyzer. ${ }^{1} \mathrm{H}$ and ${ }^{31} \mathrm{P}\left\{{ }^{1} \mathrm{H}\right\}$ NMR spectra were recorded on a Bruker Avance 400 in $\mathrm{CDCl}_{3}$ solutions. Chemical shifts are quoted relative to $\mathrm{H}_{3} \mathrm{PO}_{4} 85 \%\left({ }^{31} \mathrm{P}\right.$ external) and $\mathrm{SiMe}_{4}\left({ }^{1} \mathrm{H}\right.$, external). Mass spectra were recorded on a HP-5989B Mass Spectrometer API-Electrospray with interface 59987A. Absorption spectra in solution were registered on a Hewlett Packard 8453 Diode Array UV-visible spectrophotometer. Excitation and emission spectra were recorded on a Jobin-Yvon Horiba Fluorolog 3-22 Tau-3 spectrofluorimeter. Lifetime measurements were recorded with a Datastation HUB-B with a nanoLED controller and software DAS6 (version 6.3, ORIBA Jobin-Yvon Inc., Edison, NJ, USA). The nanoLED employed for lifetime measurements was of $371 \mathrm{~nm}$ with pulse lengths of $1.1 \mathrm{~ns}$. The lifetime data were fitted using the Jobin-Yvon software package (version 3.1, ORIBA Jobin-Yvon Inc., Edison, NJ, USA). 


\subsection{Synthesis of $\left[\mathrm{AuHg}\left(\mathrm{O}-\mathrm{C}_{6} \mathrm{H}_{4} \mathrm{PPh}_{2}\right)_{2} \mathrm{I}\right], \mathrm{I}$}

To a dichloromethane solution $(30 \mathrm{~mL})$ of $\left[\mathrm{Hg}\left(o-\mathrm{C}_{6} \mathrm{H}_{4} \mathrm{PPh}_{2}\right)_{2}\right](0.10 \mathrm{~g}, 0.13 \mathrm{mmol})$ was added an equimolecular amount of $\left[\mathrm{Au}(\mathrm{tht})_{2}\right] \mathrm{ClO}_{4}(0.06 \mathrm{~g}, 0.13 \mathrm{mmol})$ and an excess of an aqueous solution of $\mathrm{NaI}$. The reaction mixture was stirred for $24 \mathrm{~h}$ at room temperature resulting in a colorless, clear aqueous layer and an orange, clear organic layer. The mixture is shaken in a separation funnel and the organic layer was separated and washed again with $\mathrm{H}_{2} \mathrm{O}(15 \mathrm{~mL})$. Evaporation of the solvent under vacuum and addition of $n$-hexane gave rise to complex 1 as a brown solid. Yield: $76 \%$. Elemental analyses (\%) calcd for $1\left(\mathrm{C}_{36} \mathrm{H}_{28} \mathrm{AuBrHgIP}_{2}\right)$ : C 41.3, H 2.70. Found: $\mathrm{C} 41.5, \mathrm{H} 2.77 .{ }^{31} \mathrm{P}\left\{{ }^{1} \mathrm{H}\right\} \mathrm{NMR}$ (121.5 MHz, $\mathrm{CDCl}_{3}, \mathrm{ppm}$ ): $\delta 39.9$ (s, 2P). ${ }^{1} \mathrm{H} \mathrm{NMR}$ (400 MHz, $\mathrm{CDCl}_{3}, \mathrm{ppm}$ ): $\delta ~ 7.14-7.46$ (m, 28H, aromatic). $\mathrm{MS}(\mathrm{ES}+): m / z 921.11\left[\mathrm{AuHg}\left(o-\mathrm{C}_{6} \mathrm{H}_{4} \mathrm{PPh}_{2}\right)_{2}\right]^{+}$, MS (ES-): $m / z 126.90[\mathrm{I}]^{-}$.

\subsection{X-ray Crystallography Details}

The crystal was mounted in inert oil on glass fibers and transferred to the cold gas stream of a Nonius Kappa CCD diffractometer equipped with an Oxford Instruments low-temperature attachment. Data were collected using monochromated $\operatorname{MoK}_{a}$ radiation $(\lambda=0.71073 \AA)$. Scan type: $\omega$ and $\phi$. Absorption correction: semiempirical (based on multiple scans). The structure was solved by Patterson and refined on $F^{2}$ using the program SHELXL-97 [34]. All non-hydrogen atoms were refined anisotropically. Hydrogen atoms were included using a riding model. Graphics were prepared with Olex2 [35]. Further details of the data collection and refinement are given in Table 4. Selected bond lengths and angles are collected in Table 1; the crystal structure of complex $\mathbf{1}$ appears in Figure 1.

Table 4. X-ray crystallographic data is shown for complex $\mathbf{1}$.

\begin{tabular}{cc}
\hline Parameter & Compound 1 \\
\hline Formula & $\mathrm{C}_{37} \mathrm{H}_{30} \mathrm{Au} \mathrm{Cl}_{2} \mathrm{Hg} \mathrm{I}_{2}$ \\
Formula weight & 1131.91 \\
Crystal habit & Colorless prism \\
Crystal size & $0.40 \times 0.15 \times 0.15 \mathrm{~mm}^{3}$ \\
Crystal system & Monoclinic \\
Space group & $\mathrm{P} 21 / \mathrm{a}$ \\
$\mathrm{a} / \AA$ & $17.1928(4)$ \\
$\mathrm{b} / \AA$ & $11.2469(3)$ \\
$\mathrm{c} / \AA$ & $18.0925(4)$ \\
$\beta / \mathrm{deg}$ & $\beta 96.1080(10)$ \\
$\mathrm{V} / \AA^{3}$ & $3478.61(15)$ \\
$\mathrm{Z}$ & 4 \\
$\mathrm{Dc} / \mathrm{Mg} \cdot \mathrm{m}^{-3}$ & 2.161 \\
$\mathrm{Mr}$ & 9.780 \\
$\mathrm{~F}(000)$ & 2112 \\
$T / \mathrm{K}$ & 173 \\
$\theta$ range $/ \mathrm{deg}$ & $3.90-27.60$ \\
$\mathrm{No}$ rflns measd & 52126 \\
No. unique rflns & 8039 \\
$\mathrm{Rint}$ & 0.0585 \\
$\mathrm{Ra}(I>2 \sigma(\mathrm{I}))$ & 0.0278 \\
$\mathrm{Rwb}(F 2$, all rflns $)$ & 0.0377 \\
$\mathrm{Sc}$ & 1.027 \\
\hline
\end{tabular}


CCDC- 1037872 contains the supplementary crystallographic data for this paper. These data can be obtained free of charge via www.ccdc.cam.ac.uk/conts/retrieving.html (or from the Cambridge Crystallographic Data Centre, 12 Union Road, Cambridge CB2 1EZ, UK; fax: (+44) 1223-336-033; or e-mail: deposit@ccdc.cam.ac.uk).

\subsection{Computational Details}

All calculations were carried out using the Gaussian 09 program package [36] at the MP2 level of theory $[37,38]$.

Basis Sets. The 19-valence electron (VE) quasirelativistic (QR) pseudopotential (PP) of Andrae [39] was employed for gold together with two f-type polarization functions (exponents: 0.2, 1.19) [40]. Similarly, the 20-valence valence electron (VE) quasirelativistic (QR) pseudopotential (PP) of Andrae [39] was employed for mercury together with two f-type polarization functions (exponents: 0.545, 1.58) [41]. The atoms F, P, and C were treated by Stuttgart pseudopotentials [42], including only the valence electrons for each atom. For these atoms double-zeta basis sets of ref. [42] were used, augmented by d-type polarization functions [43]. For the $\mathrm{H}$ atom, a double-zeta, plus a p-type polarization function was used [44].

\section{Conclusions}

The use of asymmetric C,P-bidentate ligands allows the synthesis of a heterometallic gold(I)-mercury(II) complex showing a dinuclear arrangement including metallophilic $\mathrm{Au}(\mathrm{I}) \cdots \mathrm{Hg}(\mathrm{II})$ interactions. These are responsible for an intense blue luminesce in solid state assigned to a Charge Transfer transition from the iodide ligand to metal-based orbitals according to experimental and theoretical ab-initio studies.

\section{Acknowledgments}

This work was supported by the DGI Project (MEC)/FEDER (project number CTQ2013-48635-C22-P). The Centro de Supercomputación de Galicia (CESGA) is acknowledged for computational resources. D. Pascual thanks the CAR for a grant.

\section{Author Contributions}

JML-de-L, MM, MEO and DP conceived and designed the experiments, performed the experiments, analyzed the data and wrote the paper.

\section{Conflicts of Interest}

The authors declare no conflict of interest.

\section{References}

1. Laguna, A. Modern Supramolecular Gold Chemistry: Gold-Metal Interactions and Applications; Wiley-VCH: Weinheim, Germany, 2008. 
2. Pyykkö, P. Strong Closed-Shell Interactions in Inorganic Chemistry. Chem. Rev. 1997, 97, 597-636.

3. Pyykkö, P. Theoretical chemistry of gold. Angew. Chem. Int. Ed. 2004, 43, 4412-4456.

4. Pyykkö, P. Theoretical chemistry of gold. III. Chem. Soc. Rev. 2008, 37, 1967-1997.

5. Fernández, E.J.; López-de-Luzuriaga, J.M.; Monge, M.; Olmos, M.E.; Pérez, J.; Laguna, A.; Mohamed, A.A.; Fackler, J.P., Jr. $\left\{\mathrm{Tl}\left[\mathrm{Au}\left(\mathrm{C}_{6} \mathrm{Cl}_{5}\right)_{2}\right]\right\}_{n}$ : A vapochromic complex. J. Am. Chem. Soc. 2003, 125, 2022-2023.

6. Roundhill, D.M.; Fackler, J.P., Jr. Optoelectronic Properties of Inorganic Compounds; Plenum: New York, NY, USA, 1999.

7. Koshevoy, I.O.; Chang, Y.-C.; Karttunen, A.J.; Haukka, M.; Pakkanen, T.; Chou, P.-T. Modulation of Metallophilic Bonds: Solvent-Induced Isomerization and Luminescence Vapochromism of a Polymorphic Au-Cu Cluster. J. Am. Chem. Soc. 2012, 134, 6564-6567.

8. Catalano, V.J.; López-de-Luzuriaga, J.M.; Monge, M.; Olmos, M.E.; Pascual, D. Copper(I)-assisted red-shifted phosphorescence in $\mathrm{Au}(\mathrm{I}){ }^{\cdots} \mathrm{Cu}(\mathrm{I})$ heteropolynuclear complexes. Dalton Trans. 2014, 43, 16486.

9. Fernández, E.J.; Laguna, A.; López-de-Luzuriaga, J.M.; Monge, M.; Montiel, M.; Olmos, M.E.; Rodríguez-Castillo, M. Photophysical and Theoretical Studies on Luminescent Tetranuclear Coinage Metal Building Blocks. Organometallics 2006, 25, 3639-3646.

10. López-de-Luzuriaga, J.M.; Monge, M.; Olmos, M.E.; Pascual, D.; Rodríguez-Castillo, M. Influence of the Electronic Characteristics of N-Donor Ligands in the Excited State of Heteronuclear Gold(I)-Copper(I) Systems. Inorg. Chem. 2011, 50, 6910-6921.

11. López-de-Luzuriaga, J.M.; Monge, M.; Olmos, M.E.; Pascual, D.; Rodríguez-Castillo, M. Very Short Metallophilic Interactions Induced by Three-Center-Two-Electron Perhalophenyl Ligands in Phosphorescent Au-Cu Complexes. Organometallics 2012, 31, 3720-3729.

12. Fernández, E.J.; Laguna, A.; López-de-Luzuriaga, J.M.; Montiel, M.; Olmos, M.E.; Pérez, J.; Puelles, R.C. Mesitylgold(I) and Silver(I) Perfluorocarboxylates as Precursors of Supramolecular $\mathrm{Au} /$ Ag Systems. Organometallics 2006, 25, 4307-4315.

13. Fernández, E.J.; Hardacre, C.; Laguna, A.; Lagunas, M.C.; López-de-Luzuriaga, J.M.; Monge, M.; Montiel, M.; Olmos, M.E.; Puelles, R.C.; Sanchez-Forcada, E. Multiple Evidence for Gold(I) $\cdots$ Silver(I) Interactions in Solution. Chem. Eur. J. 2009, 15, 6222-6233.

14. López-de-Luzuriaga, J.M.; Monge, M.; Olmos, M.E.; Pascual, D. Experimental and Theoretical Comparison of the Metallophilicity between $\mathrm{d}^{10}-\mathrm{d}^{10} \mathrm{Au}^{\mathrm{I}}-\mathrm{Hg}^{\mathrm{II}}$ and $\mathrm{d}^{8}-\mathrm{d}^{10} \mathrm{Au}^{\mathrm{III}}-\mathrm{Hg}^{\mathrm{II}}$ Interactions. Inorg. Chem. 2014, 53, 1275-1277.

15. Crespo, O.; Laguna, A.; Fernández, E.J.; López-de-Luzuriaga, J.M.; Jones, P.G.; Teichert, M.; Monge, M.; Pyykkö, P.; Runeberg, N.; Schütz, M.; Werner, H.J. Experimental and theoretical studies of the $\mathrm{d}^{8}-\mathrm{d}^{10}$ interaction between $\mathrm{Pd}(\mathrm{II})$ and $\mathrm{Au}(\mathrm{I})$ : bis(chloro[(phenylthiomethyl) diphenylphosphine]gold(I))-dichloropalladium(II) and related systems. Inorg. Chem. 2000, 39, 4786-4792.

16. Fernández, E.J.; Laguna, A.; López-de-Luzuriaga, J.M.; Monge, M.; Nema, M.M.; Olmos, M.E.; Pérez, J.; Silvestru, C. Experimental and theoretical evidence of the first $\mathrm{Au}(\mathrm{I}) \cdots \mathrm{Bi}(\mathrm{III})$ interaction. Chem. Commun. 2007, 571-573. 
17. Vilma Bojan, R.; López-de-Luzuriaga, J.M.; Monge, M.; Olmos, M.E.; Echeverría, R.; Lehtonen, O.; Sundholm, D. Double Photoinduced Jahn-Teller Distortion of Tetrahedral $\mathrm{Au}^{\mathrm{I}}-\mathrm{Sn}^{\mathrm{II}}$ Complexes. ChemPlusChem 2013, 79, 67-76.

18. Fernández, E.J.; Laguna, A.; López-de-Luzuriaga, J.M.; Mendizabal, F.; Monge, M.; Olmos, M.E.; Pérez, J. Theoretical and photoluminescence studies on the $\mathrm{d}^{10}-\mathrm{s}^{2} \mathrm{Au}^{\mathrm{I}}-\mathrm{Tl}^{\mathrm{I}}$ interaction in extended unsupported chains. Chem. Eur. J. 2003, 9, 456-465.

19. López-de-Luzuriaga, J.M.; Monge, M.; Olmos, M.E.; Pascual, D. Analysis of fluorescence quenching of naphthalene by two mercury containing organometallic complexes. J. Lumin. 2014, $154,322-327$.

20. Lasanta, T.; López-de-Luzuriaga, J.M.; Monge, M.; Olmos, M.E.; Pascual, D. Experimental and Theoretical Evidence of the Existence of Gold (I) $\cdots$ Mercury (II) Interactions in Solution through Fluorescence-Quenching Measurements. Chem. Eur. J. 2013, 19, 4754-4766.

21. Fernández, E.J.; Laguna, A.; López-de-Luzuriaga, J.M.; Olmos, M.E.; Pérez, J. $\left[\left\{\mathrm{AuTl}\left(\mathrm{C}_{6} \mathrm{Cl}_{5}\right)_{2} \text { (toluene) }\right\}_{2}\right.$ (dioxane)]: A striking structure that leads to a blue luminescence. Chem. Commun. 2003, 1760-1761.

22. Fernández, E.J.; Laguna, A.; López-de-Luzuriaga, J.M.; Monge, M.; Montiel, M.; Olmos, M.E. Photophysical Studies and Excited-State Structure of a Blue Phosphorescent Gold-Thallium Complex. Inorg. Chem. 2007, 46, 2953-2955.

23. Blake, A.J.; Donamaría, R.; Lippolis, V.; López-de-Luzuriaga, J.M.; Manso, E.; Monge, M.; Olmos, M.E. Influence of Crown Thioether Ligands in the Structures and of Perhalophenyl Groups in the Optical Properties of Complexes with Argentoaurophilic Interactions. Inorg. Chem. 2014, 53, 10471-10484.

24. Lim, S.H.; Olmstead, M.M.; Balch, A.L. Inorganic topochemistry. Vapor-induced solid state transformations of luminescent, three-coordinate gold(I) complexes. Chem. Sci. 2012, 4, 311.

25. Lim, S.H.; Schmitt, J.C.; Shearer, J.; Jia, J.; Olmstead, M.M.; Fettinger, J.C.; Balch, A.L. Crystallographic and Computational Studies of Luminescent, Binuclear Gold(I) Complexes, $\mathrm{Au}_{2}{ }_{2}\left(\mathrm{Ph}_{2} \mathrm{P}\left(\mathrm{CH}_{2}\right)_{n} \mathrm{PPh}_{2}\right)_{2} \mathrm{I}_{2}(n=3-6)$. Inorg. Chem. 2013, 52, 823-831.

26. Fu, W.; Chan, K.; Miskowski, V.; Che, C.-M. The intrinsic ${ }^{3}\left[\mathrm{~d} \sigma^{*} \mathrm{p} \sigma\right]$ emission of binuclear Gold(I) complexes with two bridging diphosphane ligands lies in the near UV; Emissions in the visible region are due to exciplexes. Angew. Chem. Int. Ed. 1999, 38, 2783-2785.

27. Fu, W.F.; Chan, K.C.; Cheung, K.K.; Che, C.M. Substrate-Binding reactions of the ${ }^{3}\left[\mathrm{~d} \sigma^{*} \mathrm{p} \sigma\right]$ excited state of binuclear gold(I) complexes with bridging bis(dicyclohexylphosphino)methane ligands: emission and time-resolved absorption spectroscopic studies. Chem. Eur. J. 2001, 7, 4656-4664.

28. WebElements Periodic Table. Available online: http://www.webelements.com/ (accessed on 30 November 2014)

29. Wang, S.; Fackler, J.P., Jr. Synthesis and characterization of $\left[\mathrm{HgAu}\left(\mathrm{CH}_{2} \mathrm{SPPh}_{2} \mathrm{CH}_{2}\right)_{2}\right] \mathrm{PF} 6$, the first example of structurally characterized carbene double insertions into metal-sulfur bonds. Organometallics 1989, 8, 1578-1579.

30. Bennett, M.A.; Bhargava, S.K.; Griffiths, K.D.; Robertson, G.B.; Wickramasinghe, W.A.; Willis, A.C. Dinuclear Complexes of Gold(I) Containing Bridging Cyclometalated Arylphosphane or Arylarsane Ligands. Angew. Chem. Int. Ed. 1987, 26, 258-260. 
31. Wang, S.; Fackler, J.P., Jr. Heterobimetallic complexes of Gold and Mercury. Syntheses and characterizations of $\mathrm{Hg}^{\mathrm{II}}\left(\mathrm{CH}_{2} \mathrm{P}(\mathrm{S}) \mathrm{Ph}_{2}\right)_{2}\left(\mathrm{Au}{ }^{\mathrm{I}} \mathrm{Cl}\right)_{2}$ and $\mathrm{Hg}^{\mathrm{II}} \mathrm{Au}^{\mathrm{I}}\left(\mathrm{CH}_{2} \mathrm{P}(\mathrm{S}) \mathrm{Ph}_{2}\right)_{2} \mathrm{Au}^{\mathrm{III}} \mathrm{Cl}_{4}$. Organometallics 1990, 9, 111-115.

32. Usón, R.; Laguna, A.; Laguna, M.; Jiménez, J.; Gómez, M.P.; Sainz, A.; Jones, P.G. Gold complexes with heterocyclic thiones as ligands. X-ray structure determination of $\left[\mathrm{Au}\left(\mathrm{C}_{5} \mathrm{H}_{5} \mathrm{NS}_{2}\right] \mathrm{ClO}_{4}\right.$. Dalton Trans. 1990, 3457-3463.

33. Bennett, M.A.; Contel, M.; Hockless, D.C.R.; Welling, L.L. Bis $\{(2$-diphenylphosphino)phenyl $\}$ mercury: a novel bidentate ligand and transfer reagent for the $o-\mathrm{C}_{6} \mathrm{H}_{4} \mathrm{PPh}_{2}$ group. Chem. Commun. 1998, 21, 2401-2402.

34. Sheldrick, G.M. SHELX-97, Program for Crystal Structure Refinement; University of Göttingen: Göttingen, Germany, 1997.

35. Dolomanov, O.V.; Bourhis, L.J.; Gildea, R.J.; Howard, J.A.K.; Puschmann, H. OLEX2: A complete structure solution, refinement and analysis program. J. Appl. Crystallogr. 2009, 42, 339-341.

36. Frisch, M.J.; Trucks, G.W.; Schlegel, H.B.; Scuseria, G.E.; Robb, M.A.; Cheeseman, J.R.; Scalmani, G.; Barone, V.; Mennucci, B.; Petersson, G.A.; et al. Gaussian 09; Gaussian, Inc.: Wallingford, CT, USA, 2009.

37. Møller, C.; Plesset, M.S. Note on an Approximation Treatment for Many-Electron Systems. Phys. Rev. 1934, 46, 618-622.

38. Hehre, W.J.; Radom, L.; Schleyer, P.V.R.; Pople, J.A. Ab initio Molecular Orbital Theory; John Wiley: New York, NY, USA, 1986.

39. Andrae, D.; Häußermann, U.; Dolg, M.; Stoll, H.; Preuss, H. Energy-adjusted ab initio pseudopotentials for the second and third row transition elements. Theor. Chim. Acta 1990, 77, 123-141.

40. Pyykkö, P.; Runeberg, N.; Mendizabal, F. Theory of the $\mathrm{d}^{10}-\mathrm{d}^{10}$ Closed-Shell Attraction: 1 . Dimers Near Equilibrium. Chem. Eur. J. 1997, 3, 1451-1457.

41. Martin, J.M.L.; Sundermann, A. Correlation consistent valence basis sets for use with the Stuttgart-Dresden-Bonn relativistic effective core potentials: The atoms Ga-Kr and In-Xe. $J$. Chem. Phys. 2001, 114, 3408-3420.

42. Bergner, A.; Dolg, M.; Küchle, W.; Stoll, H.; Preuss, H. Ab initio energy-adjusted pseudopotentials for elements of groups 13-17. Mol. Phys. 1993, 80, 1431.

43. Huzinaga, S.; Andzelm, J. Gaussian Basis Sets for Molecular Orbital Calculations; Huzinaga, S., Ed.; Elsevier: Amsterdam, The Netherlands, 1984.

44. Huzinaga, S. Gaussian-type functions for polyatomic systems. I. J. Chem. Phys. 1965, 42, 1293-1302.

(C) 2015 by the authors; licensee MDPI, Basel, Switzerland. This article is an open access article distributed under the terms and conditions of the Creative Commons Attribution license (http://creativecommons.org/licenses/by/4.0/). 